This PDF is a selection from a published volume from the National Bureau of Economic Research

Volume Title: Measuring Economic Sustainability and Progress

Volume Author/Editor: Dale W. Jorgenson, J. Steven Landefeld, and Paul Schreyer, editors

Volume Publisher: University of Chicago Press

Volume ISBN: 0-226-12133-X (cloth); 978-0-226-12133-8

(cloth); 978-0-226-12147-5 (eISBN)

Volume URL: http://www.nber.org/books/jorg12-1

Conference Date: August 6-8, 2012

Publication Date: September 2014

Chapter Title: Accounting for the Distribution of Income in the U.S. National Accounts

Chapter Author(s): Dennis Fixler, David S. Johnson

Chapter URL: http://www.nber.org/chapters/c12828

Chapter pages in book: (p. 213 - 244) 


\title{
Accounting for the Distribution of Income in the US National Accounts
}

\author{
Dennis Fixler and David S. Johnson
}

The welfare of a nation can, therefore, scarcely be inferred from a measurement of national income.

—Simon Kuznets $(1934,7)$

Measured GDP growth is not the only contributor to the quality of life that Americans seek to enjoy.

_ "Economic Report of the President" (2012)

Frequent headlines present rising per capita gross domestic product (GDP) and frequent newspaper articles present people who have not shared equally in this growth (see Gertner 2010; Reinhardt 2011). This disconnect between aggregate output or income growth and its distribution to individuals has motivated a movement to examine measures of individual well-being that go beyond GDP per capita. For example, the United Nations voted (in resolution 65/309) to create a Gross National Happiness index ${ }^{1}$ because "the gross domestic product does not adequately reflect the happiness and well-being of people." Relatedly, the Organisation for Economic Co-operation and Development (OECD) recently released a guide on the measurement of subjective well-being.

Seventy years ago Kuznets (1934), in his original report on the national accounts, suggested that growth in GDP was not sufficient to evaluate social welfare. This view is echoed in the recent "Economic Report of the Presi-

Dennis Fixler is chief statistician of the Bureau of Economic Analysis. David S. Johnson is chief economist of the BEA.

Research conducted while David S. Johnson was a visiting scholar at the Russell Sage Foundation and as staff at the US Census Bureau. The authors would like to thank Ed Wolff, Chris Carroll, Steve Landefeld, and participants in the NBER Conference on Research in Income and Wealth "Measuring Economic Stability and Progress" conference. The views expressed in this chapter, including those related to statistical, methodological, technical, or operational issues, are solely those of the authors and do not necessarily reflect the official positions or policies of the Census Bureau or the Bureau of Economic Analysis, or the views of other staff members. The authors accept responsibility for all errors. This chapter is released to inform interested parties of ongoing research and to encourage discussion of work in progress. For acknowledgments, sources of research support, and disclosure of the authors' material financial relationships, if any, please see http://www.nber.org/chapters/c12828.ack.

1. See http://www.grossnationalhappiness.com for a description of the gross national happiness index developed by the Center for Bhutan studies. 
dent" and is the theme of the "Report by the Commission on the Measurement of Economic Performance and Social Progress" (or the Stiglitz, Sen, and Fitoussi [2009] report). The Stiglitz, Sen, and Fitoussi report, largely motivated by the financial crisis that started in 2007 and the consequent Great Recession, suggests that the "time is ripe for our measurement system to shift emphasis from measuring economic production to measuring people's well-being" (12).

Recent data (from 1980 to 2010) show that real per capita GDP increased 65 percent in the past thirty years, while median household income rose only 11 percent. In the past decade (between 1999 and 2010), real mean household income (from the Census Bureau) fell 5.7 percent, while real per capita personal income (from the Bureau of Economic Analysis [BEA]) increased 11.1 percent (see figure 8.1). And the recent Congressional Budget Office (CBO 2012) report shows that using a comprehensive income measure, average income decreased 0.5 percent between 1999 and 2009. Reconciling these divergent trends is one goal of this chapter.

Since its inception, the Conference on Research in Income and Wealth (CRIW) of the National Bureau of Economic Research (NBER) has been a leader in the evaluation of the distribution of income and its relationship to the national accounts. ${ }^{2}$ This chapter follows in that tradition and contributes to it by bringing together the relevant literature on the distribution of national accounts and the measurement issues associated with household income compared to national income, creating alternative measures of the median and distribution of personal income and suggesting simple methods that could be reproduced regularly. This chapter provides distributional measures of personal income, which can then inform research to determine whether the growth rate of gross domestic income (GDI) depends on changes in the income distribution.

A primary contribution of the chapter is the presentation of simple methods that adjusts the household survey (Current Population Survey [CPS]) to more closely match the national accounts measure of personal income. Using the underlying distribution in the CPS along with these adjustments yields a higher mean and median adjusted household income than the reported household income, and yields a larger increase in inequality. Adjusting the distribution by the income distribution available from tax records increases inequality further, but does not change the trend. Finally, creating a more complete measure of personal income by imputing the value of in-kind health-care benefits yields a decrease in inequality.

We include two applications that discuss how income inequality might matter in determining social welfare and gauging the efficacy of fiscal policy. Sen's (1973) original social welfare function requires estimates of both income growth and inequality; we use our estimates to examine Sen-type

2. In fact, the first NBER volume (Mitchell et al. 1921) was devoted to income distribution. 


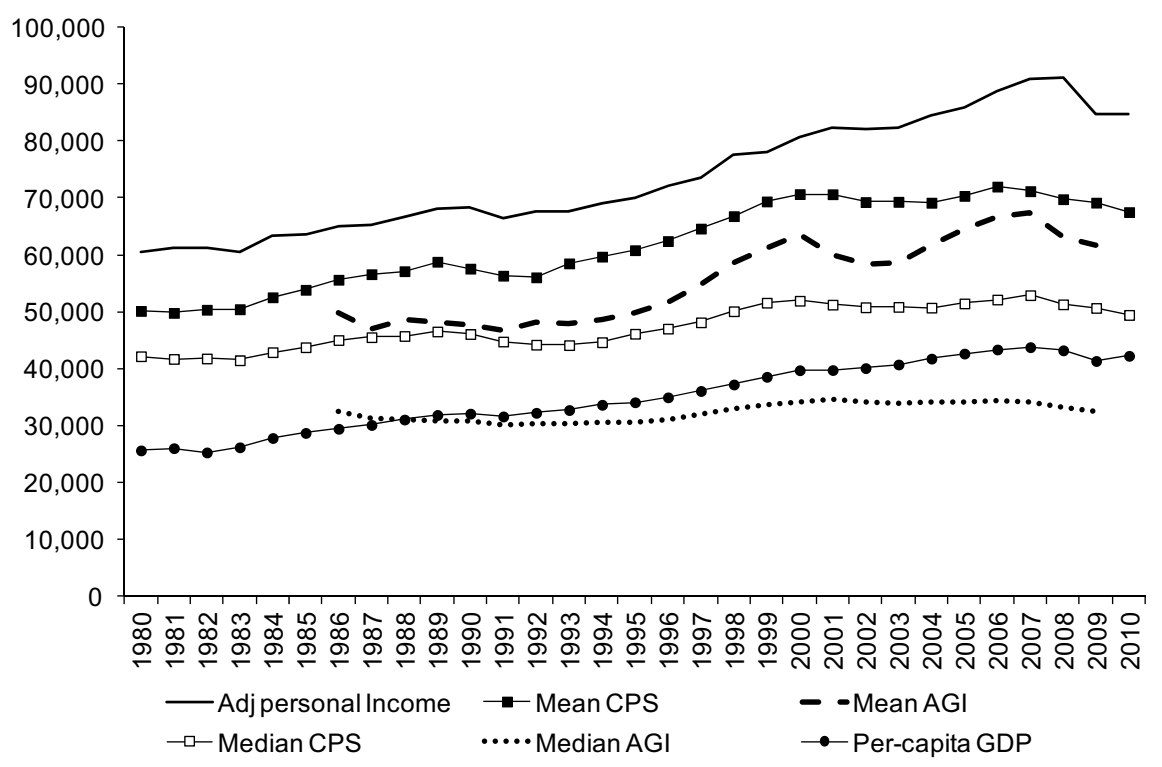

Fig. 8.1 Mean and median real household (or taxpayer) income from various measures (in 2010\$ using the PCE deflator)

social welfare functions. We also examine how income inequality bears on the measurement of the average propensity to consume and by implication the marginal propensity to consume. These measures are important to forecasting the impacts of fiscal policy on GDP. In an appendix we provide a simple model that provides an illustration of the impacts. The next section of this chapter presents alternative measures of income, previous research, and the implications of measurement error in the household data. The second section discusses the data and the results. The third and fourth sections provide applications of our results to calculating a social welfare function and examining the distribution of income and consumption, and the final section concludes this chapter.

\subsection{Measuring Income}

The BEA is responsible for producing the aggregate statistics on income growth, while the Census Bureau releases the distributional measures along with the growth in median household income. Each agency, however, uses a different measure of income. Income distribution and aggregate growth were not always separate estimates (see Goldsmith 1955, 1958 and 1960); the Office of Business Economics (the predecessor to the BEA) produced annual estimates of the income distribution from 1950 to 1962 . The BEA's national accounts measures are often interpreted at the microeconomic level 
as information on the behavior of representative consumers; however, most of the economic well-being literature requires (and measures of inequality require) more information about households across the income distribution. The question is whether the changes in the aggregate levels of economic activity are adequate indicators of the changes in individual well-being.

Since the development of national accounts, income distribution has been important in examining growth. Kuznets $(1955,27)$, in his famous paper on inequality and growth, stated: "The distribution of national product among the various groups is a subject of acute interest to many and is discussed at length in any half-articulate society." The Canberra report, the report of an expert group recommending an income measure to use in income distribution estimates, stated that the original "intention of the SNA (System of National Accounts) was to include a disaggregation of household income by socioeconomic group as a standard part of national accounts output" (Canberra Group 2011, 5).

This relationship between macroeconomic growth and income inequality has been the focus of many recent studies (see OECD 2011; Boushey and Hersh 2012). The concern is whether a rising tide is lifting all boats equally. While most studies agree that "the rich have gotten richer," the issue is whether those on the lower levels of the distribution have also experienced an improvement in their economic well-being. The question is, If growth and inequality have both increased, how has overall economic well-being changed? $?^{3}$

There is considerable disagreement regarding the relationship between inequality and growth. As suggested in a recent OECD report (OECD 2012), there is no agreement in the economics literature concerning the relationship between inequality and growth and there is no conclusive empirical evidence. The Stiglitz, Sen, and Fitoussi $(2009,8)$ report states: "If inequality increases enough relative to the increase in average per capita GDP, most people can be worse off even though average income is increasing." However, Lucas $(2004,13)$ disagrees stating: "But of the vast increase in the well-being of hundreds of millions of people that has occurred in the 200-year course of the industrial revolution to date, virtually none of it can be attributed to the direct redistribution of resources from rich to poor." Blinder (1975) provides conditions under which a redistribution would lead to increased aggregate consumption. His empirical results suggest, however, that a rise in income inequality, holding disposable income constant, would either have no effect on consumption or would actually increase it.

In order to fully evaluate the distribution and growth in income, however, we need comparable measures of income. As discussed in CRIW (1943),

3. In this chapter we focus on income, but many look to the distribution of consumption as the measure of well-being. See, for example, Meyer and Sullivan (2011) and Fisher, Johnson, and Smeeding (forthcoming). 
there are many choices that need to be made in determining the appropriate components of income to include in a measure of income distribution. We examine the distribution and movement of household income, as measured by personal income, and how it influences the movements of gross domestic income (GDI), and hence GDP. As proposed by the BEA (BEA 2012, 47), we undertake "a decomposition of personal income that presents median as well as mean income and other measures of the distribution of income across households." With the distributional aspects of personal income, one can examine how various changes in policy may impact households at various points in the distribution. Just as the BEA creates a decomposition of personal income across states and geography, this chapter provides a decomposition across the income distribution. ${ }^{4}$

The most inclusive concept of income and consumption derives from the suggestions of Haig and Simons. Haig $(1921,27)$ stated that income was "the money value of the net accretion to one's economic power between two points of time" and Simons $(1938,50)$ defined personal income as "the algebraic sum of (1) the market value of rights exercised in consumption and (2) the change in the value of the store of property rights between the beginning and end of the period in question."

Economists have used the equation that income $(Y)$ equals consumption $(C)$ plus the change in net worth $(\Delta W)$ as the working definition of Haig-Simons income $(Y=C+\Delta W)$. No household survey, however, has the necessary variables to create a full measure of Haig-Simons income. In an attempt to relate all three components, the Canberra Group Handbook on Household Income Statistics $(2011,10)$ states: "Household income receipts are available for current consumption and do not reduce the net worth of the household through a reduction of its cash, the disposal of its other financial or non-financial assets or an increase in its liabilities." Similarly, the Systems of National Accounts (SNA 2009, 160) defines household income as "the maximum amount that a household or other unit can afford to spend on consumption goods or services during the accounting period without having to finance its expenditures by reducing its cash, by disposing of other financial or non-financial assets or by increasing its liabilities." To create international standards on this Haig-Simons equation, the OECD has organized two expert groups on (a) microstatistics on household income, consumption, and wealth; and (b) disparities in the national accounts. ${ }^{5}$

The focus of this chapter is to evaluate the level, trend, and distribution of personal income (as measured by the BEA). Personal income, which consists mainly of compensation, transfer payments received, and investment income, has averaged about 85 percent of GDI over the period 1980

4. In fact, one could use the geographic decomposition to estimate a national distribution, which is the focus of future research.

5. Armour, Burkhauser, and Larrimore (2013) examine the distribution of a Haig-Simons income measure. 
to 2010. Assuming that the distribution of the extra components in GDI (beyond those in personal income) are similarly distributed, one can use the distribution of personal income to examine how various changes in policy may affect households at various points in the distribution of GDI. ${ }^{6}$

There are a multitude of income measures used by researchers and the government. Table 8.1 compares personal income, census money income, the $\mathrm{CBO}$ income measure, the adjusted gross income (AGI), and the Survey of Consumer Finances (SCF) income measure to a Haig-Simons measure and the international measure recommended by the Canberra Group (Canberra 2011). ${ }^{7}$ As table 8.1 shows, there are many components of income that are included in the measures. The first column shows those included in a Haig-Simons definition of income. Only three components are included in all income measures-employment income, investment income, and cash transfers from the government.

Looking at table 8.1, the main differences in the income definitions are the treatment of imputed income, retirement income, capital gains (realized and unrealized), unrealized interest on property income, and the inclusion of government and in-kind transfers. Even the Canberra definition, which is viewed as the standard in international comparisons, is different than the BEA definition, which follows the SNA. The values in table 8.2 provide an indication of some of the relative importance of the differences between the income measures.

Since the Census Bureau has issued its first reports on income, the bureau has distinguished between the BEA's personal income measures and the CPS household income measures. ${ }^{8}$ Personal income is the income received by persons from participation in production, from government and business transfers, and from holding interest-bearing securities and corporate stocks. Personal income also includes income received by nonprofit institutions serving households, by private noninsured welfare funds, and by private trust funds. The CPS measure of money income, produced by the Census Bureau, is defined as the total pretax money income received by people on a regular basis, excluding certain lump-sum payments and excluding capital gains.

One of the main differences among the various definitions is the treatment of retirement income. Consider an elderly person with both a savings

6. Figure 8.2 shows that the ratio between personal income and GDI has remained fairly constant between 1999 and 2010.

7. For the $\mathrm{CBO}$ measure see Harris and Sammartino (chap. 7, this volume) and for the SCF measure see Henriques and Hsu (chapter 9, this volume).

8. The first P60 reports (Census 1948, 11) stated: "The purpose of the census data is to show the distribution of families and persons by income levels. They do not show estimates of aggregate income. The Office of Business Economics estimates, on the other hand, provide information on aggregate income received by the population. If an estimate of aggregate income were derived from Census Bureau data, it would be smaller than that shown in the personal income series." 


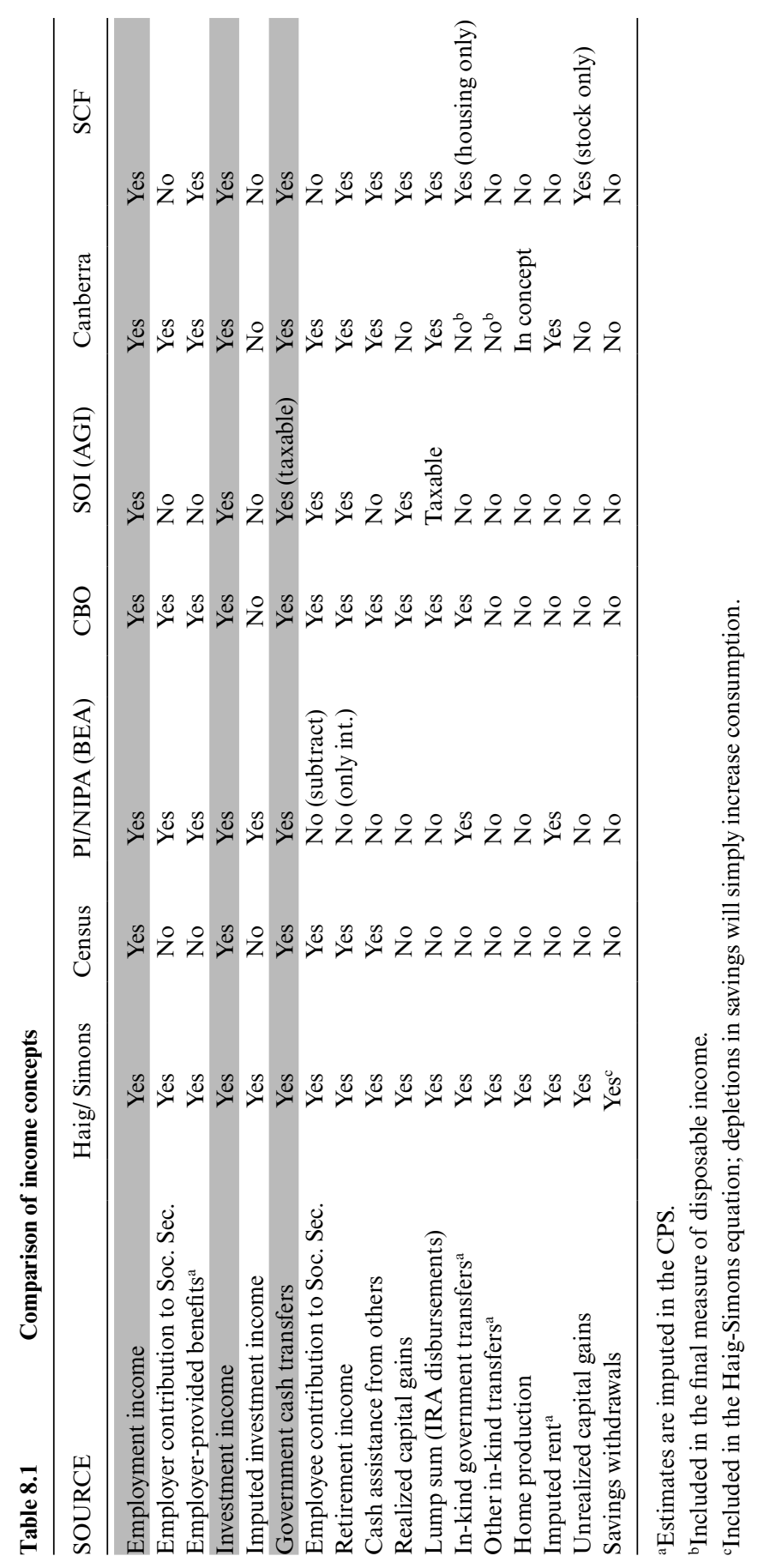


Katz (2012) categories included in adjusted personal income

\begin{tabular}{lccc}
\hline & \multicolumn{3}{c}{ Adjustment to personal income, } \\
selected years \\
\cline { 2 - 4 } & 1999 & 2007 & 2010 \\
\hline Personal income & 10,030 & 12,546 & 12,374 \\
Employer health benefits & $(450)$ & $(637)$ & $(620)$ \\
Employer pensions benefits & $(267)$ & $(396)$ & $(470)$ \\
Imputed interest & $(433)$ & $(480)$ & $(457)$ \\
Imputed rent for home owners & $(187)$ & $(68)$ & $(236)$ \\
Government transfers in-kind & $(676)$ & $(9,919)$ & $(1,132)$ \\
Adjustment for social security contributions & 428 & 526 & 514 \\
Adjustment for pension treatment & $(148)$ & 123 & 257 \\
Other adjustments & $(100)$ & $(92)$ & $(167)$ \\
Total adjustments & $(1,731)$ & $(1,943)$ & $(2,311)$ \\
Adjusted personal income & 8,299 & 10,603 & 10,062 \\
Census money income & 7,387 & 8,316 & 8,015 \\
\hline
\end{tabular}

account and a defined contribution retirement account. The interest on these accounts will be counted as income in all measures. Planned pension disbursements will also be included in all measures except personal income. If the person makes an irregular/lump-sum withdrawal from his retirement accounts, this will be recorded as income only in the Haig-Simons, CBO, and Canberra measures. Finally, if the retiree withdraws money from his or her savings account, this will only be included in Haig-Simons income because these savings withdrawals are actually decreases in net worth that will be spent. However, with other definitions of income, one would observe consumption increases with no change in income.

Most studies of income and its distribution include the money income, but do not examine changes in assets, and only a few examine the impact of capital gains (e.g., CBO 2011, 2012; Piketty and Saez 2003; Smeeding and Thompson 2011; Wolff et al. 2012; Armour, Burkhauser, and Larrimore 2013). Two recent papers present alternative measures of a more comprehensive income. Wolff et al. (2012) construct the Levy Institute Measure of Economic Well-Being (LIMEW) as the sum of census money income, income from wealth, net government expenditures (both cash and noncash transfers and public consumption, net of taxes), and household production. The "more complete income" (MCI) concept in Smeeding and Thompson (2011) is based on Haig-Simons income and estimated using Survey of Consumer Finance data. They define MCI as earnings and net transfers and include that portion of capital income received as capital gains and royalties. They subtract reported interest, rent, and dividends and include an imputed return to all forms of net worth in order to capture the concept of the change in net worth. This combines the two approaches used by the BEA and CBO 
regarding capital income, including both capital gains and imputed interest. Using MCI, Smeeding and Thompson (2011) find a larger concentration of income at the top of the distribution. Wolff et al. (2012) also show a larger increase in the mean and median using more comprehensive measures of income (see also Armour et al. 2013).

\subsubsection{Adjustments for "Real" and Equivalent Income}

Once a measure of income is determined, there are two key measurement choices that must be made in evaluating the trends and distribution in income. These choices are crucial to making comparisons over time with changing cost of living and changing demographics. The cost-of-living adjustments are made by converting dollars into constant terms using a price index, while the demographic changes are made by adjusting by household size with an equivalence scale that adjusts for the economies of scale in a household.

Slesnick (2001), Meyer and Sullivan (2011), and Broda and Weinstein (2009) show the important impact that alternative price indexes have on the increase in the mean and median, and on the inequality measures. The Census Bureau uses the CPI-U-RS to deflate household income and produce a series of mean and median income in constant dollars, and the BEA uses the personal consumption expenditure (PCE) deflator. For example, real median household income, using the CPI-U-RS, increased 10.8 percent between 1980 and 2010. However, because the PCE deflator increases less than the CPI-U-RS, if the PCE deflator is used to convert income into constant dollars, the respective increase in median household income would be 17.3 percent. Meyer and Sullivan (2011) and Boskin et al. (1996) suggest that the CPI-U (and hence, CPI-U-RS) is biased upward by 0.8 to 1.2 percentage points per year. Meyer and Sullivan (2011) use an alternative price index that adjusts the CPI-U-RS downward by 0.8 percentage points per year. Using this alternative index to create real median income yields a 40 percent increase between 1980 and 2010. Because our focus is on producing a national accounts-based income distribution, we use the PCE to convert all income into constant 2010 dollars. ${ }^{9}$

The second adjustment that is required is to account for the changes in household size over time and the respective economies of scale that may occur within households. Using a simple per capita measure (as in per capita personal income) does not deal with the economies of scale in the household, and the household measure produced by the Census Bureau simply assumes perfect economies of scale in the household. Since household size has fallen over the past thirty years, one should use a measure of household

9. The new CBO report on household income, $\mathrm{CBO}$ (2012), changed to using the PCE deflator to adjust for inflation instead of the CPI-U-RS. 
income adjusted for the household size. In this chapter, we use an equivalized measure of income using the square root of household size as the equivalence scale (see Fisher, Johnson, and Smeeding, forthcoming; Buhmann et al. 1988). Using this equivalized income shows an increase in the real median income of 17.1 percent (compared to 10.8 percent without an adjustment). Using both the equivalence-adjusted median and the PCE deflator yields a 23.9 percent increase between 1980 and 2010 .

\subsubsection{Reconciling Household and Aggregate Income}

During the first years of the CRIW, a conference was organized and a volume produced on the size distribution of income (CRIW 1943). That volume began with a chapter by Kuznets entitled "The Why and How of Distributions of Income by Size." The volume also includes a chapter that presents one of the first uses of multiple data sources to provide an estimate of the distribution of income for the United States.

The CRIW has been involved in evaluating income distribution and its impact on the national accounts for its entire history. A few volumes have been devoted to distributional issues and this new conference will produce a volume with continued research on this topic. ${ }^{10}$ In the 1975 volume, Budd and Radner (1975) present a method to use both CPS and IRS data to construct a distributional measure for the national accounts. By adjusting income by tax records, they find higher mean income and more families with high income than in the survey data. However, the income distribution shifts in such a manner as to yield a lower inequality measure than that found in the survey data. ${ }^{11}$

In the spirit of these first volumes, from 1950 to 1962, the Office of Business Economics produced annual measures of the income distribution in the United States. Goldsmith (1955) creates a distribution measure and continues with regular releases in the Survey of Current Business (see also Goldsmith 1960). These estimates also show higher mean incomes than those in the CPS, but the inequality measures, both levels and trends, are similar to those in the CPS data.

There are various methods to obtain a distribution of aggregate data. In all cases, one needs both the aggregate data and a household survey. Fesseau, Bellamy, and Raynaud (2009) and Accardo et al. (2009) use distribution of survey data to create a distribution for national account data in France. This relies on the assumption that the distribution in the household survey is the same as in the national accounts. Landefeld et al. (2010) create a median

10. Juster edited the 1975 CRIW volume The Distribution of Economic Well-Being," and in 1980, Smith edited Modeling the Distribution and Intergenerational Transmission of Wealth, and David and Smeeding edited Horizontal Equity, Uncertainty, and Economic Well-Being in 1985.

11. For example, using their tables shows that the adjusted Gini is lower than the Gini from the CPS. The adjustment basically shifts the entire distribution to the right. 
discretionary income measure using the distribution in the IRS Statistics of Income (SOI) tables. Coli and Tartamella (2010) and McColl et al. (2010) both attempt to reconcile survey and national accounts data for Italy and Australia. Other methods are to create a social accounting matrix (as in Mussard and Savard 2010) or to use a reweighting procedure to adjust the survey estimates of inequality. The method presented in this chapter uses a household survey and benchmarks it to the aggregate totals.

\subsubsection{Underreporting in Household Surveys}

Katz (2012) shows that the changes in census household income are similar to a comparable measure of personal income between 1980 and 1999, but diverge in recent years. He suspects that much of the difference occurs because of property (or capital) income (interest, dividends, etc.). One possible reason for the difference in both the distribution and the growth rates can be the underreporting of income in the CPS. Meyer, Mok, and Sullivan (2008) show that for all surveys examined (including the CPS) there is evidence of income under-reporting, which has tended to increase over time.

Recently, there have been papers that attempted to reconcile differences between the BEA and census measures of household income. Weinberg (2006) and Ruser, Pilot, and Nelson (2004) examine the quality of CPS data. Ruser, Pilot, and Nelson (2004), a joint effort between the BEA and Census Bureau, demonstrates that the CPS underestimates the income in the national accounts data for many components. They construct a reconciliation between BEA personal income and census household income, and show that most of the discrepancy is due to definitional differences. However, the remaining differences can be due to the different sources, which could suggest that the administrative tax data may better represent the distributional aspects of GDI.

The presence of underreporting (measured as the difference between the survey data and the aggregate data) will not only affect the means and growth rates of income, but will also impact the change in inequality. As shown in Bound, Brown, and Mathiowitz (2001) and Gottschalk and Huynh (2010), if measurement error is classical, independent of income (or consumption), then an increase in error will increase inequality (and measured inequality could be biased upward). Gottschalk and Huynh (2010), however, extend this result to nonclassical measurement error, which could be mean reverting. In this case, it is not clear whether measurement error (or an increase in error) increases inequality. Hence, increased measurement error can imply an increase or a decrease in inequality of the reported resource measure. If the measurement error is correlated with income, such that higher income households are increasingly likely to underreport their income, then mean reversion in measurement error increases. As a result, measured inequality (and increases in inequality) could be biased downward. 


\subsection{Data and Results}

To construct measures of income and its distribution, we use the CPS Annual Social and Economic Supplement (ASEC). The CPS/ASEC includes about 100,000 households who are interviewed from February to April of each year and asked about the previous year's income. While some of the tables and figures depict income and inequality since 1980, we focus on the 1999 to 2010 period. During this period, the ratio of aggregate CPS money income to adjusted personal income (explained below) fell from 89 percent (in 1999) to 80 (see figure 8.2 and Katz [2012]).

There are important conceptual differences between the BEA's measure of real personal income and the Census Bureau's measure of real money income. Many components of personal income are not included in money income and a number of components of money income are not included in personal income (see Katz 2012). Conceptually, the BEA personal income measures the income of the entire household sector and nonprofit institutions serving households (NPISHs). In contrast, the money income concept at the Census Bureau measures the incomes of individual families and persons, which can be used to examine the distribution of income across all families and persons (excluding people in institutions).

To directly compare the income estimates in the CPS to those in the national accounts, we need to use comparable income measures. We follow Katz (2012) to construct an adjusted personal income measure (see table 8.2) that matches the money income measure from the CPS. As shown in

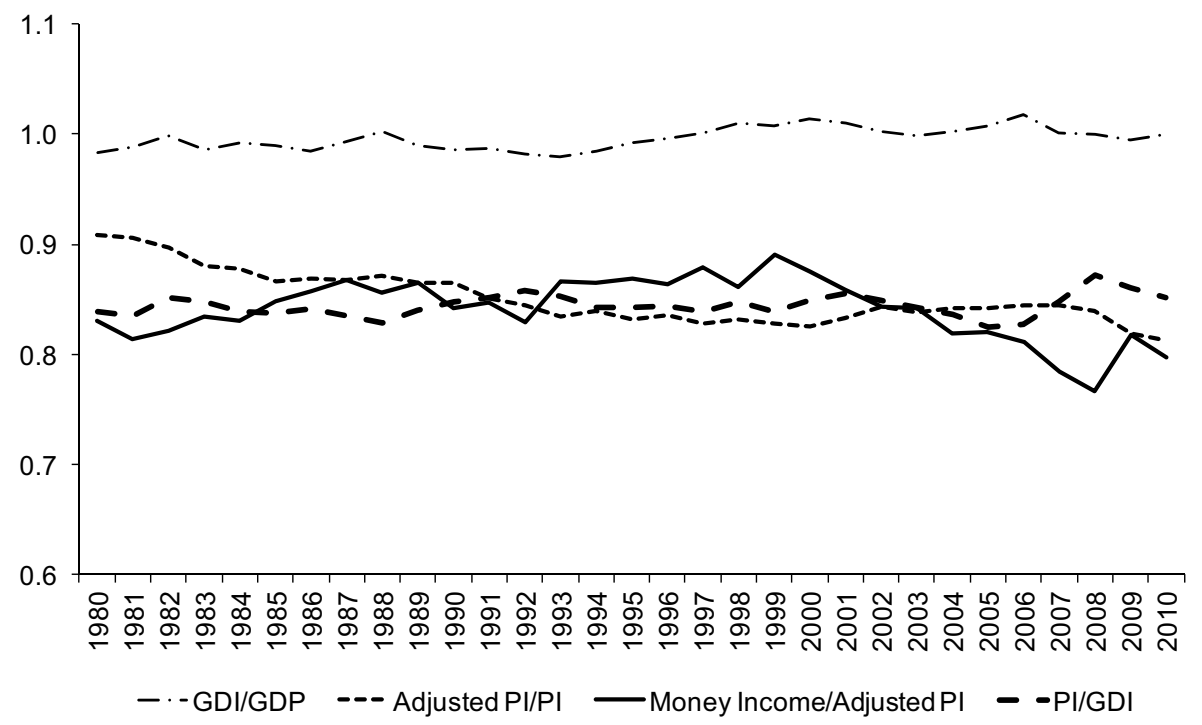

Fig. 8.2 The ratios of various measures of real aggregate income 
table 8.2, most of the adjustments take various types of in-kind income out of personal income, including employer benefits, government in-kind transfers, imputed rent from owner-occupied housing, and imputed interest from life insurance reserves. In addition, pensions are measured by benefits paid rather than by employer contributions to pension funds, and the income earned on the plan assets (reserves) and employee contributions to social insurance are added back into personal income because they are included in money income, but not personal income. Adjustments are also made to take out the income of nonprofit institutions and to add in transfers between and among households. ${ }^{12}$

With these adjustments, the levels are more similar (as shown in table 8.2 and figure 8.2) and the trends from 1980 to 2010 show both series increasing at similar rates between 1980 and 1999, but diverging between 1999 and 2010 , with the ratio falling from 89 percent to 80 percent. Table 8.2 shows that personal income increased 23.4 percent between 1999 and 2010, while adjusted income increased 21.2 percent because the adjustments increased 33.5 percent between 1999 and 2010, with one of the largest increases being the doubling of government transfers of health care. ${ }^{13}$

We assume that the household survey data are underreported because the aggregate estimates are less than those obtained in the national accounts data. A simple method to obtain a distribution of personal income from the national accounts is to use the income distribution in the CPS. In this case, the mean and median are simply ratio adjusted by the same amount (and hence, inequality remains unchanged).

Another simple method would be to use the median-adjusted gross income (AGI) in the SOI tables. Figure 8.1 shows the changes in the mean and median AGI from the SOI tables between 1999 and 2009 (the latest year available) and compares these to the CPS income measures. As shown, the median AGI falls 1.5 percent compared to a fall of 3.3 percent for CPS median income. In addition, similar to the CPS mean income, mean AGI falls by 2.9 percent and is much more volatile than personal income (mainly due to the inclusion of capital gains in AGI).

Landefeld et al. (2010) follows a different approach and uses the distributional tax tables to obtain a change in median AGI by finding the income category that contains the median of the number of returns and then computing the mean of the category. They also adjust the reported income from the SOI tables to include additional income sources that are included in personal income, but excluded from AGI. These adjustments are small and increase at a similar rate to the unadjusted income sources. Hence, we

12. Semega (2012) shows a similar comparison between the Canberra income and household income.

13. Table 9 in Katz (2012) provides details on the components of income in the BEA measure and the CPS. This table can also be compared to a similar method used by McCully (chapter 6 , this volume). 
Table 8.3

Shares for components on CPS money income, by total income

\begin{tabular}{lccccc}
\hline Income level & Wages (\%) & $\begin{array}{c}\text { Business } \\
\text { income (\%) }\end{array}$ & $\begin{array}{c}\text { Property } \\
\text { income (\%) }\end{array}$ & $\begin{array}{c}\text { Government } \\
\text { transfers (\%) }\end{array}$ & $\begin{array}{c}\text { Retirement } \\
\text { income (\%) }\end{array}$ \\
\hline Less than 50,000 & 57 & 5 & 3 & 29 & 6 \\
$50,000-200,000$ & 84 & 4 & 4 & 4 & 4 \\
200,000 or more & 84 & 6 & 7 & 1 & 2 \\
All & 83 & 5 & 5 & 9 & 4 \\
\hline
\end{tabular}

can compare this approach to the overall changes in the median AGI presented in figure 8.1. In contrast to the results in figure 8.1 that suggest a decrease of 0.2 percent between 2000 and 2007, Landefeld et al. $(2010,18)$ find, for 2000 to 2007, "a rough measure of real after-tax income for the median income taxpayer rose at a 1.2 percent annual rate," which implies an approximate 8 percent increase. In fact, if we were to use a comparable measure of taxpayer income, the methods used in Landefeld et al. (2010) suggest an increase of 8.2 percent between 2000 and 2007 (and the adjusted income increases 7.4 percent), which is much higher than that shown using the median AGI reported by SOI. ${ }^{14}$

In order to change the distribution in the CPS, different factors are needed for different households. Since the income composition varies at different points in the distribution, we could use alternative factors to ratio adjust the various sources of income. These adjustments could then change the overall distribution of income. Table 8.3 shows the income component shares by total income level in the CPS for 2010. This table shows that the share of property and interest income is higher for the highest income group.

We consider two adjustment methods. First, consider, household $i$, with income, $y_{i}=\sum_{j} \alpha_{j} y_{j i}\left(y_{j i}\right.$ is the $j^{\text {th }}$ component of household $i$ 's income), where the adjustment factors, $\alpha_{j}$, depend on the source, $j$, of income (e.g., wages or interest/dividends) and are given by the ratio of aggregate personal income to aggregate CPS income $\left(\alpha_{j}=Y_{j} / X_{j}\right.$, where $Y_{j}$ is the aggregate for source $j$ in the personal income measure [in the NIPAs] and $X_{j}$ is the aggregate for source $j$ in the CPS). This procedure increases each household's income by source and the new adjusted household data is then used to obtain distribution measures. ${ }^{15}$

To illustrate, consider only one source of income, such as wages. Then the adjusted income for household $i$ would be given by [NIPA wages/CPS wages] $\times$ CPS wages for household $i$, and similarly add additional sources of income. This procedure generates a NIPA-based adjusted income series for households in the CPS and thereby yields an NIPA-based income distribution.

14. Estimates calculated using underlying tables provided by the BEA.

15. The simple ratio-adjustment mentioned above is for $\alpha_{j}=\alpha$ for all sources. 


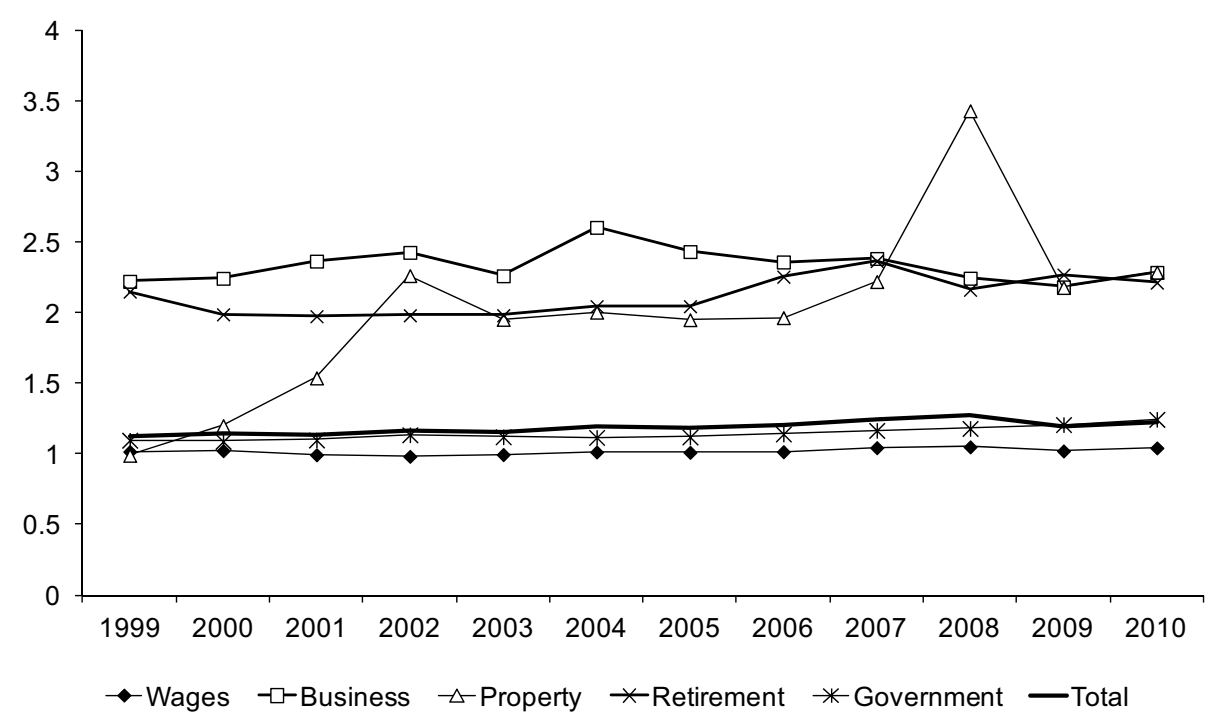

Fig. 8.3 Ratio of CPS aggregate income to NIPA income, adjustment factors $-\alpha_{j}$ (Katz 2012)

These NIPA adjustments are shown in figure 8.3. The adjustments for wages are fairly small, but the adjustments for property income (interest and dividends) are large and increase over time. ${ }^{16}$ As shown in table 8.3, higherincome households have more property income, which also has a larger factor (see figure 8.3). Hence, these households obtain a larger increase in their adjusted income, which can increase inequality.

One limitation of the above approach is that every household receives the same adjustment for each source of income even though it is likely that different households have different levels of underreporting. In addition, research has shown that there is a large underreporting at the top of the distribution (see Sabelhaus et al., forthcoming). To assess these differences, we compare the distribution of income in the CPS to that in the SOI published tables. ${ }^{17}$

To illustrate the way we remove the limitation of a constant adjustment factor for each household source of income, we include another factor that adjusts for different income groups. Again, considering just wages, the adjusted income for household $i, y_{i}$ becomes

16. Comparing the wage distribution (and levels) shows that the trend of wages in the CPS is similar to that in NIPA and SOI (see also Nichols, Smith, and Wheaton [2011]; Turek et al. [2012]; and Roemer [2000]).

17. The adjustments used in this chapter compare the average income by source for taxpayers ranked by their total AGI and compares these to the aggregate income by source for households in the CPS. Households and taxpayers are slightly different. Nichols, Smith, and Wheaton (2011) attempt to correct for the unit of analysis, and obtain similar ratios. 


$$
y_{i}=\frac{\text { NIPAwages }}{C P S w a g e s} \times \frac{\left.\frac{\text { SOIwages }}{C P S w a g e s}\right|_{\text {incomegroupk }}}{\left.\sum_{k} \frac{\text { SOIwages }}{C P S w a g e s}\right|_{\text {incomegroupk }}} \times \text { wages }_{C P S, i},
$$

where income group $k$ follows from the level of CPS income for household $i$. In general, household $i$ has income $y_{i}=\sum_{j k} \gamma_{j k} \alpha_{j} y_{j k i}$, where the adjustment factors, $\alpha_{j}$, depend on the source (as above), and $\gamma_{j k}=\left(Y_{j k} / X_{j k}\right) /\left(Y_{j} / X_{j}\right)$, where $Y_{j k}$ is the aggregate for source, $j$, for income group, $k$, in SOI tables and $X_{j k}$ is the aggregate for source, $j$, for income group, $k$. As a result, the first adjustment factor, $\alpha_{i}$, is augmented by the distributional information for the source-income combination from SOI data. Other sources of income would be added to the right-hand side of the above equation in a similar manner, yielding NIPA-based adjusted income series that derives from the CPS income data. From this series another distribution of income is obtained. As shown in figure 8.4, the ratio of income in the CPS to that in the SOI tables falls with income and is 1.3 for the highest income.

To adjust income by different factors for each source and income level in our second adjustment method, we use the aggregate income by source for various levels of total AGI in the SOI tables. ${ }^{18}$ We allow the $\gamma_{j k}$ to depend on various income levels (that is, the factors for each source can vary for different households across the income distribution). Since we want to benchmark to the aggregate personal income, the distribution factors are only used to redistribute income and are normalized so that the average factor is 1 .

The results of these methods are shown in table 8.4. As expected, the NIPA adjustments yield a higher mean and median, and increase the changes over time. For example, in 2010, the mean NIPA-adjusted household income is 21.4 percent higher than the census money income, and the median is 17.5 percent higher. Although census median household income falls 3.6 percent between 1999 and 2010, the NIPA-adjusted household income increases 1.9 percent. The increase in the NIPA-adjusted mean income exceeds the increase in the NIPA-adjusted median by more than the corresponding increase with census money income, which suggests that inequality increases more under the NIPA-adjusted income. ${ }^{19}$

Using the SOI-adjusted data increases the volatility of the mean and median (as can be seen in figure 8.1), and hence, increases the volatility of the Gini coefficient shown in table 8.6. Although the distribution of property income is highly skewed in the SOI data, the large factors for high-income households are offset by similarly large factors for low-income households (see figure 8.4). This U-shaped pattern for wages and business income in

18. See "SOI Tax Stats-Individual Statistical Tables by Size of Adjusted Gross Income" at http://www.irs.gov/taxstats/indtaxstats/article/0,,id=96981,00.html.

19 . With a log normal distribution, the ratio of mean to median income represents a measure of inequality. 


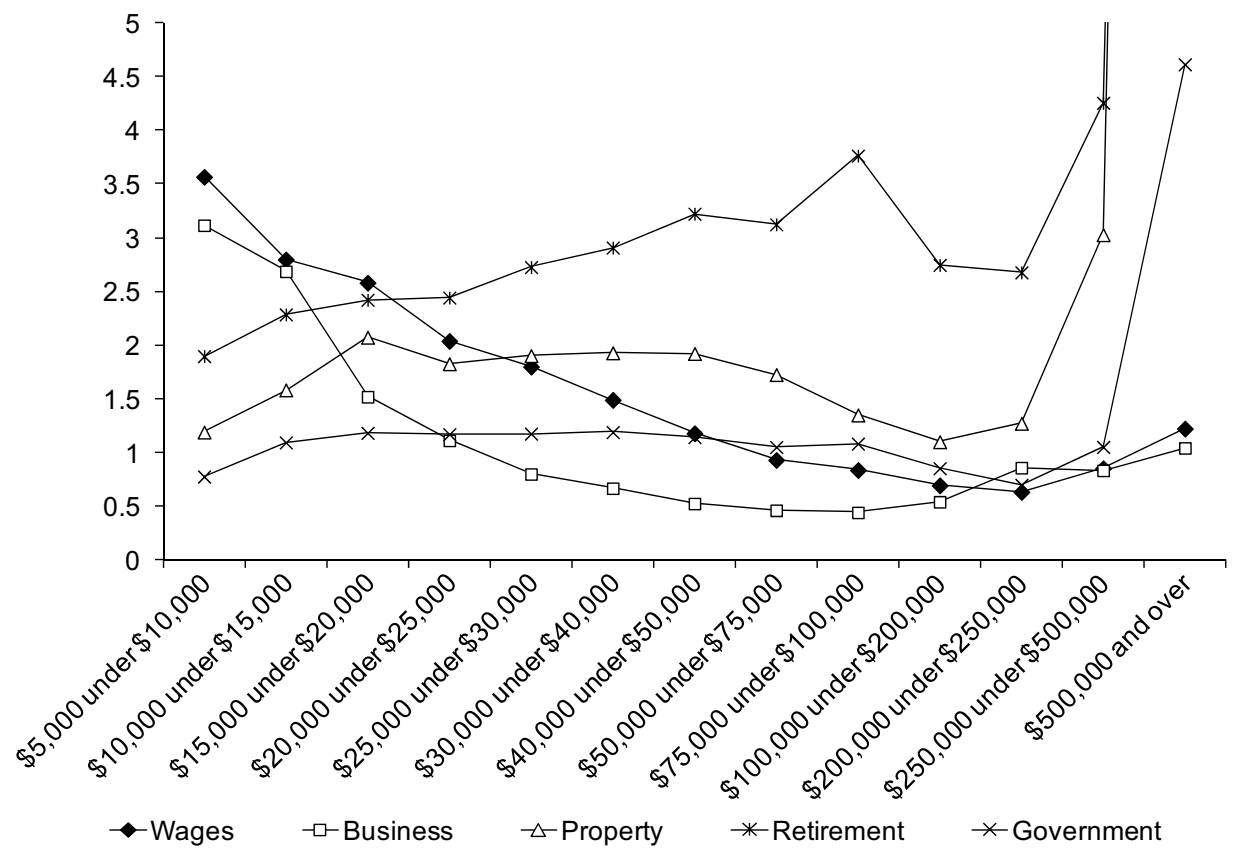

Fig. 8.4 SOI factors used to adjust CPS income (ratio of aggregate income by source for level of AGI), factors, $-\gamma_{j k}$

Table 8.4

Mean and median real household income using alternative adjustments (in 2010\$)

\begin{tabular}{lccccccc} 
& $\begin{array}{c}\text { Mean } \\
\text { money } \\
\text { income }\end{array}$ & $\begin{array}{c}\text { Median } \\
\text { money } \\
\text { income }\end{array}$ & $\begin{array}{c}\text { Mean } \\
\text { NIPA- } \\
\text { adjusted } \\
\text { income }\end{array}$ & $\begin{array}{c}\text { Median } \\
\text { NIPA- } \\
\text { adjusted } \\
\text { income }\end{array}$ & $\begin{array}{c}\text { Mean } \\
\text { SOI dist- } \\
\text { adjusted } \\
\text { income }\end{array}$ & $\begin{array}{c}\text { Median } \\
\text { SOIdist- } \\
\text { adjusted } \\
\text { income }\end{array}$ & $\begin{array}{c}\text { Adjusted } \\
\text { personal } \\
\text { income per } \\
\text { household }\end{array}$ \\
\hline 999 & 69,110 & 50,945 & 77,773 & 56,674 & 78,237 & 66,006 & 80,474 \\
2000 & 70,100 & 51,820 & 79,586 & 57,294 & 80,778 & 65,806 & 82,697 \\
2001 & 70,341 & 50,986 & 79,726 & 56,539 & 81,511 & 63,644 & 83,442 \\
2002 & 68,981 & 50,472 & 79,621 & 56,705 & 80,471 & 66,012 & 83,196 \\
2003 & 69,287 & 50,609 & 79,529 & 56,718 & 81,273 & 66,010 & 83,139 \\
2004 & 68,829 & 50,339 & 81,688 & 57,474 & 82,795 & 68,179 & 85,262 \\
2005 & 70,042 & 51,043 & 82,748 & 57,507 & 83,230 & 65,987 & 86,262 \\
2006 & 71,672 & 51920 & 85,801 & 59,190 & 86,410 & 68,074 & 88,734 \\
2007 & 70,934 & 52,660 & 87,574 & 61,472 & 88,467 & 69,085 & 90,648 \\
2008 & 69,458 & 50,995 & 88,071 & 60,664 & 90,319 & 67,831 & 90,445 \\
2010 & 68,840 & 50,279 & 81,907 & 58,137 & 82,678 & 66,535 & 84,536 \\
Percent change & 67,516 & 49,109 & 81,946 & 57,739 & & & 84,769 \\
$(1999-2010)$ & $-2.3 \%$ & $-3.6 \%$ & $5.4 \%$ & $1.9 \%$ & $5.7 \% 0^{\mathrm{a}}$ & $0.8 \%{ }^{\mathrm{a}}$ & $5.3 \%$ \\
\hline
\end{tabular}

${ }^{\text {a From }} 1999$ to 2009. 


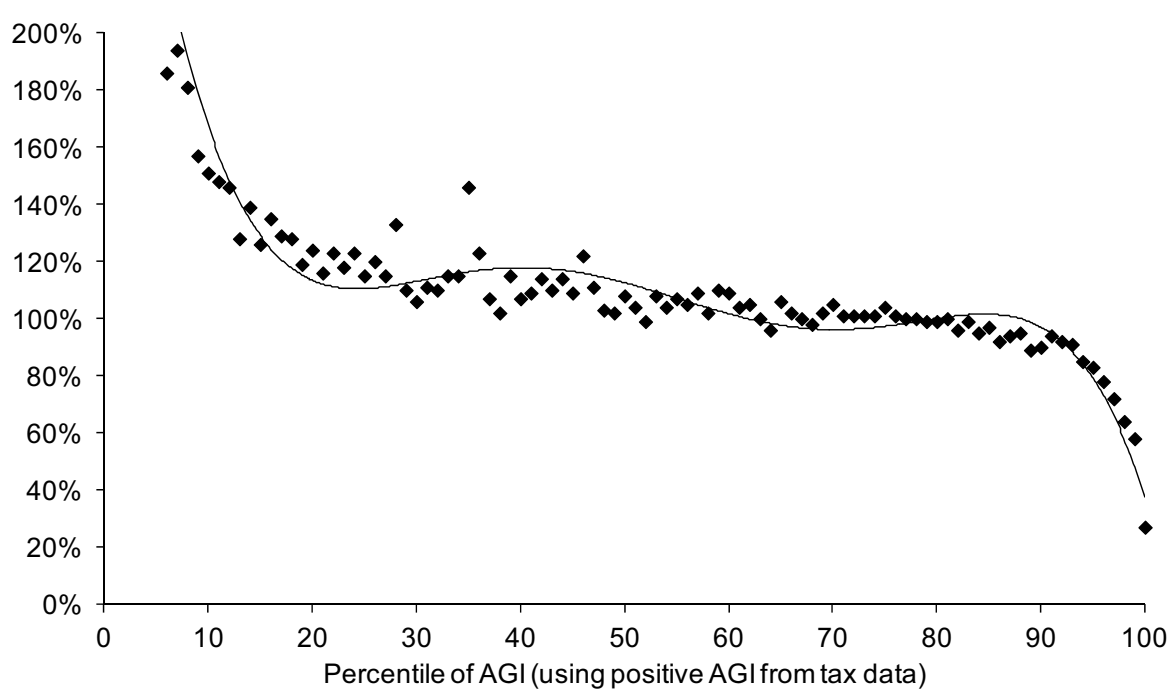

Fig. 8.5 Ratio of CPS AGI income to tax form 1040 AGI income, by AGI percentile, 2010

figure 8.4 is due partly to the use of households in the CPS and taxpayers in the SOI data, which may yield smaller AGI levels at the lower end of the distribution for the SOI taxpayers. ${ }^{20}$ Since the SOI data are only used to redistribute income, and the NIPA adjustments are used to benchmark income, the SOI-adjusted mean increases at a rate similar to the NIPA-adjusted mean. However, because of the slight U-shaped pattern in the factors shown in figure 8.4, the median SOI-adjusted income increases only 0.8 percent between 1999 and 2009 (the latest year for which SOI data are available), compared to a 2.5 percent increase for the NIPA-adjusted median. ${ }^{21}$

A more accurate method for adjusting for underreporting in the CPS would be to use the actual tax records data matched to the CPS. ${ }^{22}$ Using the 2010 IRS 1040 data linked to the CPS data, we can compare the income distributions. Figure 8.5 shows that the ratio of CPS to IRS income is fairly constant until the higher levels of income. Similar to Sabelhaus et al. (forthcoming), the largest differences are in the high income categories and using the tax data yields a larger Gini coefficient. ${ }^{23}$

20. Future work includes creating a more comparable measure of AGI using tax-filing units in the CPS.

21. Some of the differences between the Gini coefficients using the SOI adjusted income and the SOI tables is due to the differences between households and taxpayers.

22. Sabelhaus et al. (forthcoming) demonstrate that high-income households are missing from the Consumer Expenditure Survey, and suggest that the CPS similarly suffers.

23. The Gini coefficient in 2010 for the matched AGI tax income is .489 as compared to .449 for the AGI from the CPS. Further research includes obtaining data for 1999, and additional years to compare trends. 
Table 8.5

Mean and median real household income, adjusted to include noncash benefits (in 2010\$)

\begin{tabular}{lcccc}
\hline & $\begin{array}{c}\text { Mean (NIPA- } \\
\text { adjusted with } \\
\text { health benefits) }\end{array}$ & $\begin{array}{c}\text { Median (NIPA- } \\
\text { adjusted with } \\
\text { health benefits) }\end{array}$ & $\begin{array}{c}\text { Mean (NIPA- } \\
\text { adjusted with } \\
\text { all imputations) }\end{array}$ & $\begin{array}{c}\text { Median (NIPA- } \\
\text { adjusted with } \\
\text { all imputations) }\end{array}$ \\
\hline 1999 & 86,709 & 65,113 & 97,850 & 70,351 \\
2000 & 88,892 & 66,550 & 100,177 & 71,706 \\
2001 & 89,725 & 66,227 & 97,949 & 70,195 \\
2002 & 90,078 & 66,926 & 95,757 & 69,955 \\
2003 & 90,500 & 67,155 & 96,844 & 70,795 \\
2004 & 93,066 & 68,435 & 98,882 & 71,690 \\
2005 & 94,573 & 69,144 & 100,684 & 72,498 \\
2006 & 97,824 & 71,264 & 103,828 & 74,531 \\
2007 & 99,846 & 73,406 & 105,920 & 76,662 \\
2008 & 100,422 & 72,982 & 103,921 & 75,625 \\
2009 & 94,867 & 71,243 & 103,032 & 75,085 \\
2010 & 95,028 & 71,013 & 103,197 & 74,945 \\
Percent change & & & & $6.5 \%$ \\
$(1999-2010)$ & $9.6 \%$ & $9.1 \%$ & $5.5 \%$ & 6 \\
\hline
\end{tabular}

While the money income measure produced by the Census Bureau excludes many of the components of income included in personal income, the Census Bureau attempts to impute some of these components. We can use these imputed values to obtain a measure of household income in the CPS that is more comparable to personal income, which contains items denoted in table 8.1 (Table 8.1 denotes these items by footnote a, which includes the market value of Medicare and Medicaid, employer contributions to health insurance, and imputed value of home equity for home owners.) Similar to Burkhauser, Larrimore, and Simon (2010) and Meyer and Sullivan (2011), including the imputations for health-care benefits yields an even greater increase in the mean and median and a smaller increase in inequality. ${ }^{24}$

All of these adjusted measures can then be used to determine inequality. The Gini coefficient is the most commonly used measure (see CBO 2011; Burkhauser, Larrimore, and Simon 2010; and Fisher, Johnson, and Smeeding, forthcoming). Table 8.6 shows the Gini coefficients from these adjusted measures. Similar to the relationship between the mean and medians, the NIPA-adjusted measure yields a larger increase in inequality (a 2.7 percent increase between 1999 to 2010 compared to 1.9 percent for the household income measure).

As shown in table 8.5, the inclusion of imputed health-care benefits (either from the employer or government) not only increases income, but

24. Burkhauser, Larrimore, and Simon (2010) and Meyer and Sullivan (2011) show that the median has increased between 25 percent and 50 percent between 1979 and 2007; CBO (2011) shows a 20 percent increase. 


\begin{tabular}{|c|c|c|c|c|c|c|}
\hline & $\begin{array}{l}\text { Money } \\
\text { income }\end{array}$ & $\begin{array}{l}\text { NIPA- } \\
\text { adjusted } \\
\text { income }\end{array}$ & $\begin{array}{l}\text { SOI dist- } \\
\text { adjusted } \\
\text { Income }\end{array}$ & $\begin{array}{l}\text { NIPA adj, with } \\
\text { health, } \\
\text { retirement, and } \\
\text { imputed interest }\end{array}$ & $\begin{array}{c}\text { Money } \\
\text { income with } \\
\text { health benefits }\end{array}$ & $\begin{array}{c}\text { Census research } \\
\text { income } \\
(\text { definition } 14)^{\mathrm{a}}\end{array}$ \\
\hline 1999 & 0.425 & 0.441 & 0.427 & 0.428 & 0.400 & 0.408 \\
\hline 2000 & 0.426 & 0.443 & 0.443 & 0.431 & 0.400 & 0.410 \\
\hline 2001 & 0.430 & 0.452 & 0.459 & 0.426 & 0.399 & 0.412 \\
\hline 2002 & 0.426 & 0.451 & 0.445 & 0.416 & 0.395 & 0.405 \\
\hline 2003 & 0.428 & 0.451 & 0.450 & 0.416 & 0.396 & 0.394 \\
\hline 2004 & 0.429 & 0.456 & 0.440 & 0.419 & 0.393 & 0.404 \\
\hline 2005 & 0.433 & 0.460 & 0.452 & 0.423 & 0.395 & 0.402 \\
\hline 2006 & 0.435 & 0.461 & 0.451 & 0.424 & 0.396 & 0.405 \\
\hline 2007 & 0.426 & 0.455 & 0.456 & 0.417 & 0.394 & 0.403 \\
\hline 2008 & 0.430 & 0.465 & 0.468 & 0.417 & 0.396 & 0.392 \\
\hline 2009 & 0.434 & 0.452 & 0.433 & 0.419 & 0.399 & 0.392 \\
\hline 2010 & 0.433 & 0.453 & & 0.417 & 0.398 & \\
\hline $\begin{array}{l}\text { Percent change } \\
\quad(1999-2010)\end{array}$ & $1.9 \%$ & $2.7 \%$ & $1.4 \% 0^{\mathrm{b}}$ & -2.6 & $-0.5 \%$ & $-3.9 \%$ \\
\hline
\end{tabular}

${ }^{a}$ See http://www.census.gov/hhes/www/cpstables/032010/rdcall/toc.htm. For a complete description of definition 14, see http://www.census.gov/hhes/www/poverty/prevcps/p60-186rd.pdf.

${ }^{\text {b}}$ From 1999 to 2009.

also increases the change in income between 1999 and 2010. In addition, table 8.6 shows that these income sources decrease inequality (and lower the increase in the trend) as they are more likely to accrue to low-income households. The Census Bureau constructs an alternative income measure of after-tax-and-transfer income that also includes the imputed value of Medicare, Medicaid, employer-provided health insurance (definition 14), and shows a decrease in inequality between 1999 and 2009 (the latest year available). ${ }^{25}$

Burkhauser, Larrimore, and Simon (2010) show that including the value of government health-care benefits causes the change in inequality between 2000 and 2007 to increase less than the inequality using money income. Similarly, CBO (2011) shows that including health-care benefits yields a smaller increase in inequality between 1999 and 2007. Using a more comprehensive income measure, Wolff et al. (2012) find a larger increase in the median income between 2000 and 2004 (an increase of 0.6 percent) compared to a decrease of 1 percent for the standard money income definition. Wolff et al. (2012) also find a smaller increase in inequality during this period.

25. See http://www.census.gov/hhes/www/cpstables/032010/rdcall/toc.htm. For a complete description of definition 14, see http://www.census.gov/hhes/www/poverty/prevcps/p60-186rd .pdf. 
To obtain a closer approximation of personal income, we could use the same adjustments to account for the imputed interest and employer-provided retirement benefits. ${ }^{26}$ As shown in table 8.2, these components account for most of the remaining difference between adjusted personal income and personal income. If we assume that these are distributed similar to wages and reported property income, we simply increase these two factors, $\alpha_{\text {Wage }}$ and $\alpha_{\text {property }}$. Table 8.5 shows that this more comprehensive measure yields an increase in the mean of 5.5 percent and in the median of 6.5 percent. ${ }^{27}$

In sum, we began with the fact that over the past decade (between 1999 and 2010) the mean household income (from the Census Bureau) fell 5.7 percent, while per capita personal income (from the Bureau of Economic Analysis [BEA]) increased 11.1 percent, which can be construed as a difference of 16.8 percentage points with the assumption that persons per household is constant over time. Using a more comparable definition of income and national accounts data, we found that the mean-adjusted real personal income per household increased 5.3 percent during this period. In comparison, using the CPS data and after taking into account differences in the price index, accounting for underreporting and incorporating distributional information from both the CPS and SOI data, we obtain an increase of 5.7 percent (between 1999 and 2009) so that the adjustments reduce the difference between national accounts and census data on mean household income to 0.4 percent. In addition, with the adjusted measures of income there are larger increases in the median, yielding larger increases in inequality. However, as discussed above, the comparison is not straightforward when one considers imputations such as those for health benefits. Thus, to determine comparable changes in inequality there are two dimensions to the analysis: the reconciliation of published data and the definition of the "best" concept of income to use in determining well-being. Since the choice of the income measure depends on the use of the measure, we do not recommend one particular income measure for use in assessing inequality.

\subsection{Determining a Social Welfare Function: An Application}

There has been much research on obtaining independent measures of various social welfare functions that depend on both the level of aggregate income and its distribution (see Sen [1973]; Jorgenson [1990]; Jones and

26. Future work will include measures of imputed rent as measured by the return on home equity.

27. An additional method to obtain a Gini is to decompose the Gini using alternative measures of the income components. Using Lerman and Yitzhaki (1985) and Liberati and Yitzhaki (2011), the Gini can be decomposed by source as $G=\sum S_{j} G_{j} R_{j}$, where is the share of source, $S_{j}$, in income, $G_{j}$ is the Gini for source, $j$, and $R_{j}$ is the correlation between the source and the total income. Using a variety of sources can then be used to estimate the separate factors, $S, R$, and the source-specific Ginis. One can then aggregate these factors to obtain the overall Gini. 
Klenow [2011]; Jorgenson and Slesnick, chapter 3, this volume). All of these measures attempt to aggregate the mean level of growth with changes in the distribution as measured by an inequality index (like the Gini).

Over the past three decades, the Gini coefficient increased along with per capita GDP, with a correlation of .92. Sen (1973) recommends a social welfare function (SWF) that is simply the product of mean income, $\mu$, and a measure of equality given by (1-Gini). Many studies have recommended using a similar SWF or indicator of social welfare. Jorgenson $(1990,1012)$ constructs a consistent SWF such that "the individual welfare function and the individual expenditure function can be used to construct measures of the household standard of living and its cost." He then uses the same data and structure to estimate an equity index to obtain a SWF measure as the product between adjusted expenditures and equity, which is similar to Sen's SWF (see also Jorgenson and Slesnick, chapter 3, this volume).

Jones and Klenow (2011) follow a different approach and construct a SWF for a variety of countries using GDP, the Gini indexes, and other factors. Their data suggest that the Sen SWF (using the product of per capita GDP and [1-Gini]) yields a correlation (for a variety of countries) between the Jones and Klenow (2011) SWF and Sen's measure of .95.

If aggregate income growth is the result of increases in the income for households at the top of the distribution, then this growth may be offset by increases in inequality, which could yield a smaller increase in the SWF. That is, if inequality increases, then the equity index (using 1-G) falls, which diminishes the growth of SWF. For example, using a simplified SWF as the product of real per capita GDP and (1-the census Gini for money income), SWF increases about 48 percent between 1980 and 2009 (per capita GDP increases 65 percent and the Gini increases 16 percent). However, using the more comprehensive measure of household income from CBO (2012), which increases 20 percent, yields a 35 percent increase in SWF.

In order to completely evaluate the relationship between inequality and growth, we need measures of both using similar concepts (as in Jorgenson 1990). Many attempts have been made to create a summary welfare measure using GDP growth and distributional measures from household surveys. However, if there is measurement error, then inequality can be biased upward or downward, depending on the level of mean reversion. And if error is increasing over time, then inequality increases could be biased downward, while growth could be more accurate.

We can examine the recent decade (from 1999 to 2010) by using the results in the previous section (and tables 8.5 and 8.6) and construct consistent SWFs. Using per capita GDP and the census household Gini (as mentioned above) yields an increase in the SWF of 5.9 percent between 1999 and 2010. Using the household-adjusted personal income measure (as the $\mu$ ) and the respective Gini (using the similarly adjusted data) yields an increase in SWF of 3.1 percent. However, using the more complete income measure that 
includes health benefits yields a 7.4 percent increase in SWF mainly because of a fall in inequality (shown in table 8.6). ${ }^{28}$

\subsection{Distribution of Income and Consumption: An Application}

Inasmuch as consumption is the major component of GDP, macroeconomic theory has focused, from its inception, on consumer behavior. A key indicator of this behavior is the average propensity to consume (APC). Keynes (1964) maintained that the APC declines with income. But Kuznets (1946) did not find such a decline in the data and in fact found that the APC was relatively stable with income. Friedman's (1957) permanent income hypothesis nor the Modigliani and Brumberg (1954) life cycle model sought to explain the stability of the APC. All of these discussions, however, were in the context of average or representative consumers.

The presence of heterogeneous agents, however, suggest that there is a distribution of income across them and hence, a distribution of propensities to consume. More specifically, if the propensities to consume differ by income groups then there is both a cross-sectional and time series dimension to the APC. Accordingly, two questions are of interest. First, at a point in time, how does the APC change across income categories? Second, over time, as incomes change, how does the APC for different income categories behave? We can use our methods to provide insight into the second question and leave the first question for future research.

Using the ratio of personal consumption expenditures (PCE) to personal disposable income, we can see an increase over time in the aggregate APC, with a recent fall. Between 1999 and 2010, the aggregate APC fell from 93 percent to 92 percent (see figure 8.6). ${ }^{29}$ Alternatively, Fisher, Johnson, and Smeeding (forthcoming) calculate the APC using household-level data from the Consumer Expenditure (CE) Survey, and find a similar slight decrease from 83 to 82 percent between 1999 and 2010.

Information on APC by income quintile is not readily available; however, Fisher, Johnson, and Smeeding (forthcoming) create the APCs by quintile using the CE data. For 2010, they find APCs of 1.4, 1.0, 0.9, 0.8, and 0.7 for quintiles one to five, respectively (with an overall APC of .82). We can also use the results in McCully (chapter 6, this volume) to create adjusted income and expenditures by quintile and obtain APCs that would be consistent with personal income and PCE. Using tables 6.4 and 6.5 from McCully (chapter

28. These changes in the SWF can be compared to a similar measure presented in Jorgenson and Slesnick (chapter 3, this volume). They obtain a standard-of-living index using their equity index and their measure of real PCE per equivalent household member. This measure increases 14.5 percent between 1999 and 2010 mainly due to a large increase in equivalence-adjusted PCE, which increases 18 percent (as compared to the 10 percent increase in per capita GDP).

29. Using personal income instead of disposable income yields a similar result, but with lower APCs. 


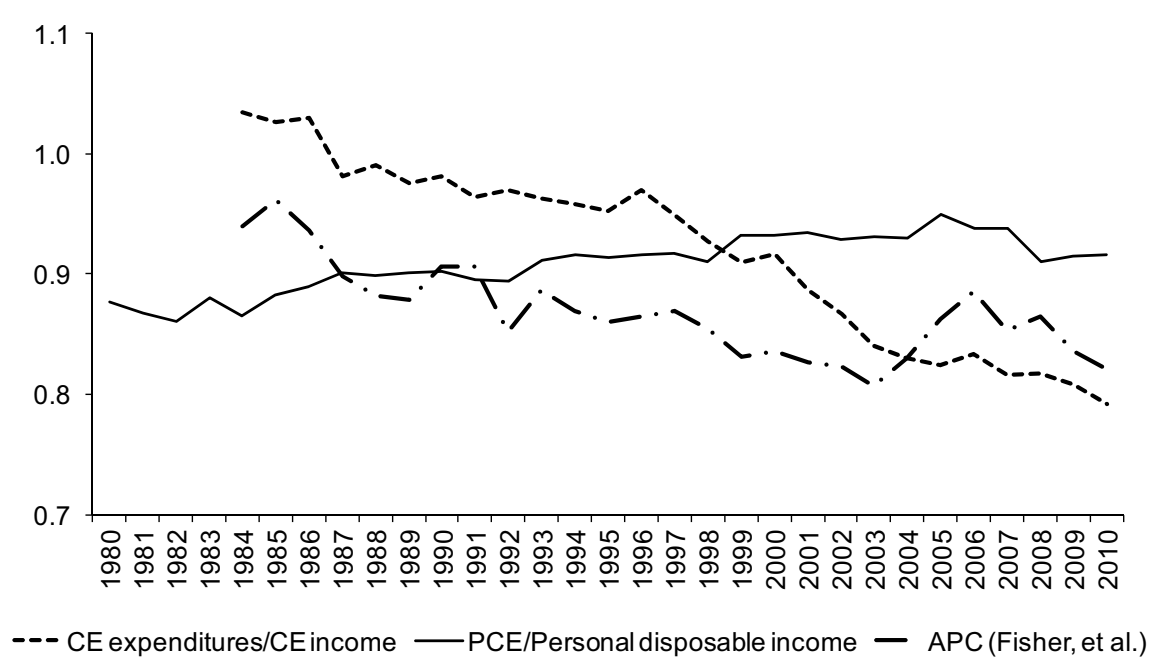

Fig. 8.6 Various average propensities to consume (APC)

6 , this volume), we obtain APCs by quintiles of $2.3,1.4,1.1,0.9$, and 0.5 for an overall APC of 0.89 (which is still lower than the aggregate APC given above).

Figure 8.6 provides a sense of how information on consumption by income quintile can matter. First, observe the relative stability of the aggregate APC using national income account data relative to the aggregate APC using CE data. Since the income and consumption components of the latter differ from those in the former, the difference provides further evidence on the importance of the domains of consumption and income. As shown above, using the Fisher, Johnson, and Smeeding (forthcoming) and McCully (chapter 6, this volume) APCs by income quintle demonstrate that the average APC is quite different from that obtained using aggregate NIPA data. This difference provides further evidence of the need to determine the distribution of consumption and income using national income account data, which will be the subject of future work. Finally, an implication of these different APCs by income quintile is examined further in the appendix.

\subsection{Conclusion}

Since their beginnings, the NBER and the CRIW have been concerned about the distribution of income and its relationship to the national accounts. Sixty years ago in his American Economic Association presidential address, Kuznets began by asking the question: "Does inequality in the distribution of income increase or decrease in the course of a country's economic growth?" He continued by arguing that the distribution of income must be linked to the measure of national income. Using previous work on creating 
a comparable measure of personal income in the CPS, we have provided a couple simple methods to produce a median personal income and its Gini coefficient.

These methods yield a variety of results on the growth of median income and inequality, depending on the definition of income used and the method used to obtain the distribution. Stiglitz, Sen, and Fitoussi $(2009,13)$ argued that averages must "be accompanied by indicators that reflect their distribution. Median consumption (income, wealth) provides a better measure of what is happening to the 'typical' individual or household than average consumption (income or wealth)." We showed that adjusting for the underreporting in the CPS yields a larger level and increase in the trend of the mean and median between 1999 and 2010. This, in turn, yields a larger increase in inequality. Using a more comprehensive income measure that includes the government- and employer-provided health benefits yields a flatter trend in inequality.

In future work we will improve the methods presented in this chapter by evaluating other methods to adjust for nonreports in the CPS data. That is, the current method only adjusts for the underreporting given a positive report of income; however, some "zero" reports may also be underreported income. In addition, the concordance used to compare the CPS measure to the personal income measure (described in table 8.2 and presented in Katz [2012]) needs to be compared to the methods presented in McCully (chapter 6 , this volume).

Another method to obtain an improved measure of underreporting involves analysis of the matched household data with the tax records. A more complete method of determining the aggregate impacts of the joint distribution of income and consumption requires similar decompositions of PCE and personal income that rely on the distribution of the household survey data.

There are two dimensions to the analysis: the reconciliation of published data and the definition of the "best" concept of income to use in determining well-being. The results in this chapter may provide a framework for developing measures of median personal income, GDI, and their distribution that could be produced on a regular basis.

\section{Appendix}

\section{A Simple Multiplier Analysis for the Different APCs by Income Quintile}

One chief application of the APC is constructing an autonomous expenditure multiplier. If propensities to consume are higher for lower-income groups, then the autonomous expenditure multipliers might be higher, which 
in turn suggests that the efficacy of government expenditures in enhancing economic growth might be improved by income redistribution.

The multiplier analysis presented here is but one facet of the identification of the relationship between income inequality and growth. ${ }^{30}$ Regarding the linkage between the propensity to consume, the income distribution, and macroeconomic analysis, Keynes (1964) thought that:

The amount that the community spends on consumption obviously depends (i) partly on the amount of its income, (ii) partly on the other objective attendant circumstances, and (iii) partly on the subjective needs and the psychological propensities and habits of the individuals composing it and the principles on which the income is divided between them (which may suffer modification as output is increased) . . . . But, in general, we shall in what follows take the subjective factors as given; and we shall assume that the propensity to consume depends only on changes in the objective factors. ${ }^{31}$

Keynes places the income distribution in the category of a subjective factor. ${ }^{32}$ Stone and Stone (1938), in support of Keynes, also examine the relationship between the marginal propensity to consume and the income distribution and find no relationship. Haavelmo (1945) looked at the same question in terms of the impact on the balanced budget multiplier. Goodwin (1949) and Chipman (1950) looked at the multiplier as a matrix across sectors, the latter allowing for income redistribution, and Conrad (1955) used a similar method to look at the income effects of redistribution.

To illustrate how our estimates can be used to evaluate an autonomous expenditure multiplier, we consider a very simple model that abstracts from many of the complexities to estimating multipliers that have been addressed in recent studies of the magnitude of multipliers. ${ }^{33}$ In particular, we do not consider the dynamic complexities of consumer behavior, the role of uncertainty, the stance of monetary policy, or the stage of the business cycle. The purpose of the example below is not to add to the discussion about the magnitude of the multiplier, but rather to show in a simplified way how the incorporation of income distribution might impact an expenditure multiplier.

We consider a very simple closed Keynesian model (similar to Chipman [1950]) in which the autonomous expenditure component captures all expenditures save a consumption expenditure that is a fraction of income. We ignore taxes as well as that can be viewed as simply a change in income. Let $Y_{i}$

30. The relationship between income inequality and growth has been the focus of many studies. Both positive and negative relationships have been posited and supported by empirical evidence (see, for example, Forbes [2000] and Berg and Ostry [2011]).

31. Book III, chapter 8, page 91 .

32. It should be pointed out that in other parts of Keynes (1964), there are references to the potential efficacy of income redistribution. See, for example, section II in chapter 19 and chapter 24.

33. See, for example, Auerbach and Gorodnichenko (2012), Christiano, Eichenbaum, and Rebelo (2011), and Ramey (2012). 
denote income, $A_{i}$ autonomous expenditure, and $c_{i}$ the marginal propensity to consume for the $i$ th income class

$$
\begin{aligned}
Y_{i} & =A_{i}+c_{i} Y_{i} \mathrm{i}=1 \ldots N . \\
d Y_{i} & =d A_{i}+c_{i} d Y_{i}
\end{aligned}
$$

The model shows that for income category, its marginal propensity to consume determines the sector expenditure multiplier and thereby the aggregate multiplier. Specifically, for $N$ income categories, we can compute the impact of a change in autonomous expenditures in each category and then add up across categories to obtain the aggregate expenditure multiplier.

The system can be written as

$$
\left(1-c_{i}\right) d Y_{i}=d A_{i} .
$$

or in matrix form

$$
\left[\begin{array}{c}
d Y_{1} \\
\vdots \\
d Y_{N}
\end{array}\right]=[I-C]^{-1}\left[\begin{array}{c}
d A_{1} \\
\vdots \\
d A_{N}
\end{array}\right]
$$

where

$$
C=\left[\left(\begin{array}{ccc}
c_{1} & \ldots & 0 \\
\vdots & \ddots & \vdots \\
0 & \cdots & c_{N}
\end{array}\right)\right]
$$

Let $I$ denote the identity matrix and $D$ be the determinant of $[I-C]$, and let $D_{i}$ be the determinant of the matrix resulting from the substitution of

$$
\left[\begin{array}{c}
d A_{1} \\
\vdots \\
d A_{N}
\end{array}\right]
$$

into the $i$ th column of $[I-C]$, then $d Y_{i}=D_{i} / D$ and $d Y=\sum_{i=1}^{N}\left(D_{i} / D\right)$.

Using quintiles, we have

$$
D=\Pi_{i}\left(1-c_{i}\right) \text {, and } D_{i}=\left(\Pi_{j \neq j}\left(1-c_{j}\right)\right) .
$$

If $c=c_{i}$ for all $i$, then we obtain the usual expenditure multiplier, $5 /(1-c) .{ }^{34}$ The implication is that taking into account different propensities to consume by income category can have significant effects on the

34. Suppose $N=2$. Then have the total change multiplier arising from all the $d A i$ and $d Y=$ $\left(2-c_{1}-c_{2}\right) /\left(1-c_{1}-c_{2}-c_{1} c_{2}\right)$, and a finite solution requires $c_{1}+c_{2}+c_{1} c_{2}<1$. If $c_{1}=c_{2}=c$ then we obtain the usual expenditure multiplier $(2 / 1-c)$, where the 2 derives from there being two sectors. 
value of the autonomous expenditure multiplier. To compare this with the simple textbook multiplier that assumes constant MPC we would divide the $N$-sector multiplier by $1 / N$ so as to obtain the textbook $1 /(1-c)$.

Using the APCs discussed in the text, the MPC can be found by assuming that the elasticity of consumption with respect to income, $\varepsilon$, is constant across income categories and over time and given by 0.1 (as in Dynan 2012 and Oh and Reis 2011). ${ }^{35}$ Since $\varepsilon=$ MPC/APC, then the MPCs are basically one-tenth of the APCs. Using the average APC above yields an average MPC of .092.

Recall that Fisher, Johnson, and Smeeding (forthcoming) find for 2010 APCs of $1.4,1.0,0.9,0.8$, and 1.7 for quintiles one to five, respectively (with an overall APC of 0.82 ). Using an elasticity of 0.1 yields MPCs of 0.14 , $0.10,0.09,0.08$, and 0.07 . Using the simple expenditure multiplier equations given above yields a multiplier of 1.11 compared to the multiplier for constant MPCs of 1.09, for a difference of $0.02 .{ }^{36}$ As a result, an equalizing redistribution will have a small positive impact on the change in income.

We can use the results in McCully (chapter 6, this volume) to create adjusted income and expenditures by quintile and obtain APCs that would be consistent with personal income and PCE. Using tables 6.1 and 6.2 from McCully (chapter 6, this volume), we obtain a steeper pattern of APCs, which yields a larger divergence in MPCs between the top and bottom quintiles, and hence, a slightly larger change in the multipliers with a transfer multiplier of 0.05 .

It is reasonable to ask how sensitive these findings are to the selected income consumption elasticity. Consider again the APCs from Fisher, Johnson, and Smeeding (forthcoming). If the elasticity is increased from 0.1 to 0.4 the difference between the multiplier using the average MPC and the one that uses the quintile MPCs rises from 0.02 to 0.18 ; a huge increase. ${ }^{37}$ This result further demonstrates the point we made earlier; namely, that we are considering a very simple model.

\section{References}

Accardo, J., V. Bellamy, G. Consales, M. Fesseau, S. Laidier, and E. Raymaud. 2009. "Inequalities between Households in the National Accounts-Breakdown of Household Accounts." INSEE Working Paper, National Institute of Statis-

35. Oh and Reis (2011) use an average MPC of 0.11 in their estimates of the effectiveness of government transfers, and Parker et al. (2013) find MPCs ranging from .12 to .30.

36. Oh and Reis (2011), using a more robust model of redistribution and MPCs that are decreasing with income, find a similarly small positive impact of redistribution.

37. The elasticity of 0.4 is chosen because it is near the maximum that preserves a positive determinant for the I-C matrix. The impact of the increase in the elasticity qualitatively holds for the other APCs as well. 
tics and Economic Studies. http://www.insee.fr/en/themes/document.asp?ref_id $=$ ECOFRA09d.

Armour, P., R. V. Burkhauser, and J. Larrimore. 2013. "Deconstructing Income and Income Inequality Measures: A Crosswalk from Market Income to Comprehensive Income." American Economic Review 103 (3): 173-7.

Auerbach, A., and Y. Gorodnichenko. 2012. "Measuring the Output Responses to Fiscal Policy." American Economic Journal: Economic Policy 4:1-27.

BEA (Bureau of Economic Analysis). 2012. "Economic and Statistical Analysis Budget Estimates, Fiscal Year 2012, as Presented to Congress." February 2011.

Berg, A., and J. D. Ostry. 2011. "Inequality and Unsustainable Growth: Two Sides of the Same Coin?" International Monetary Fund, IMF Staff Discussion Note, SDN/11/08. April 8. http://www.imf.org/external/pubs/cat/longres.aspx ?sk=24686.0.

Blinder, A. 1975. "Distribution Effects and the Aggregate Consumption Function." Journal of Political Economy 83 (3): 447-75.

Boskin, M., E. Dulberger, R. Gordon, Z. Grilliches, and D. Jorgenson. 1996. "Toward a More Accurate Measure of the Cost of Living." Final Report to the Senate Finance Committee, December 4. http://www.ssa.gov/history/reports/boskin rpt.html.

Bound, J., C. Brown, and N. Mathiowitz. 2001. "Measurement Error in Survey Data." In Handbook of Econometrics, edited by J. J. Heckman and E. Leamer, 3707-45. Amsterdam: Elsevier Science B.V.

Boushey, H., and A. Hersh. 2012. "The American Middle Class, Income Inequality, and the Strength of Our Economy New Evidence in Economics." Center for American Progress report, May. http://www.americanprogress.org/issues/economy /report/2012/05/17/11628/the-american-middle-class-income-inequality-and-the -strength-of-our-economy/.

Broda, C., and D. E. Weinstein. 2008. Prices, Poverty, and Inequality: Why Americans Are Better Off than You Think. Washington, DC: AEI Press.

Budd, E., and D. Radner. 1975. "The Bureau of Economic Analysis and Current Population Survey Size Distributions: Some Comparisons for 1964." In The Personal Distribution of Income and Wealth, edited by James D. Smith. New York: National Bureau of Economic Research.

Buhmann, B., L. Rainwater, G. Schmauss, and T. Smeeding. 1988. "Equivalence Scales, Well-being, Inequality, and Poverty: Sensitivity Estimates across Ten Countries Using the Luxembourg Income Study Database.” Review of Income and Wealth 34:115-42.

Burkhauser, R., J. Larrimore, and K. Simon. 2010. "A 'Second Opinion' On The Economic Health Of The American Middle Class.” NBER Working Paper no. 17164, Cambridge, MA.

Canberra Group. 2011. Handbook on Household Income Statistics, 2nd ed. United Nations Economic Commission for Europe. http://www.unece.org/index.php ?id=28894.

Census Bureau. 1948. "Current Population Reports, Consumer Income, 1947." Series P-60, Number 4.

Chipman, J. 1950. "The Multisector Multiplier." Econometrica 18 (4): 355-74.

Christiano, L., M. Eichenbaum, and S. Rebelo. 2011. "When Is the Government Spending Multiplier Large?” Journal of Political Economy 119:78-121.

Coli, A., and F. Tartamella. 2010. "Micro-Macro Integration: Survey Data on Household Income for the Estimate of the Italian GDP." IARIW Conference Paper, International Association for Research in Income and Wealth. http://www .iariw.org/abstracts/2010/7A/coli.pdf.

Conference on Research in Income and Wealth. 1943. "Comparability and Deficien- 
cies of Existing Data and the Construction of a Size Distribution for the United States." In Income Size Distributions in the United States, Part I, Conference on Research in Income and Wealth. New York: National Bureau of Economic Research.

. 2011. "Trends in the Distribution of Household Income Between 1979 and 2007." CBO Report.

. 2012. "The Distribution of Household Income and Federal Taxes, 2008 and 2009.” CBO Report.

Conrad, Alfred. 1955. "The Multiplier Effects of Redistributive Public Budgets." Review of Economics and Statistics 37 (2): 160-73.

Council of Economic Advisors. 2012. Economic Report of the President, 2012. Washington, DC: GPO. http://www.whitehouse.gov/administration/eop/cea/economic -report-of-the-President.

Dynan, K. 2012. "Is a Household Debt Overhang Holding Back Consumption?" Brookings Papers on Economic Activity Spring: 229-344.

Fesseau, M., V. Bellamy, and E. Raynaud. 2009. "Inequality between Households in the National Accounts." International Institute of Statistics and Economic Studies, INSEE Premier No. 1265A. http://www.insee.fr/en/themes/document.asp ?ref_id=ip1265.

Fisher, J., D. Johnson, and T. Smeeding. Forthcoming. "Inequality of Income and Consumption in the US: Measuring the Trends in Inequality from 1984-2010 for the Same Individuals." Review of Income and Wealth.

Forbes, K. J. 2000. "A Reassessment of the Relationship Between Inequality and Growth." American Economic Review 90 (4): 869-87.

Friedman, M. 1957. "The Permanent Income Hypothesis." In A Theory of the Consumption Function, edited by M. Friedman. Princeton, NJ: Princeton University Press.

Gertner, J. 2010. "The Rise and Fall of GDP.” New York Times, May 13.

Goldsmith, S. 1955. "Income Distribution in the United States, 1950-53." Survey of Current Business, March. Washington, DC: GPO.

- 1958. "The Relation of Census Income Distribution Statistics to Other Income Data." In An Appraisal of the 1950 Census Income Data, Studies in Income and Wealth, vol. 23, Conference on Research in Income and Wealth. New York: National Bureau of Economic Research.

- 1960. "Size Distribution of Personal Income, 1956-59." Survey of Current Business, April. Washington, DC: GPO.

Goodwin, R. M. 1949. "The Multiplier as Matrix.” Economic Journal 59 (236): 537-55.

Gottschalk, P., and M. Huynh. 2010. "Are Earnings Inequality and Mobility Overstated? The Impact of Non-Classical Measurement Error." Review of Economics and Statistics 92 (2): 302-15.

Haavelmo, Trygve. 1945. "Multiplier Effects of a Balanced Budget." Econometrica 13 (4): $311-8$.

Haig, Robert M. 1921. "The Concept of Income-Economic and Legal Aspects." Federal Income Tax, 1-28. New York: Columbia University Press.

Holdren, A. E., and B. Grimm. 2008. "Gross Domestic Income: Revisions and Source Data." Survey of Current Business, December. Washington, DC: GPO.

Jones, C., and P. Klenow. 2011. "Beyond GDP? Welfare across Countries and Time." NBER Working Paper no.16352, Cambridge, MA.

Jorgenson, D. W. 1990. "Aggregate Consumer Behavior and the Measurement of Social Welfare." Econometrica 58 (5): 1007-40.

Katz, A. 2012. "Explaining Long-term Differences between Census and BEA Measures of Household Income." BEA Working Paper. 
Keynes, John, M. 1964. The General Theory of Employment, Interest and Money. New York: Harcourt, Brace \& World, Inc. First published in 1936.

Kuznets, Simon. 1934. "National Income, 1929-1932." 73rd US Congress, 2nd session, Senate document no. 124.

Kuznets, S. 1955. "Economic Growth and Income Inequality." American Economic Review 45 (1): 1-28.

Landefeld, S. J., B. R. Moulton, J. D. Platt, and S. M. Villones. 2010. "GDP and Beyond: Measuring Economic Progress and Sustainability." Survey of Current Business, April. Washington, DC: GPO.

Lerman, R., and S. Yitzhaki. 1985. "Income Inequality Effects by Income Source: A New Approach and Applications to the United States." Review of Economics and Statistics 67 (1): 151-6.

Liberati, P., and S. Yitzhaki. 2011. "GDP and Beyond: An Implementation of Welfare Considerations to the Distribution of Earnings in Italy." Department of Economics, University Roma Tre, Unpublished manuscript.

Lucas, R. E., Jr. 2004. "The Industrial Revolution: Past and Future." The Region, Minneapolis Federal Reserve Bank, May.

McColl, B., J. Billing, B. Kindermann, and H. Burgess. 2010. "Micro and Macro Economic Estimates for Australian Households: Recent Developments and Future Directions." Paper presented at the International Association for Research in Income and Wealth (IARIW) annual meetings, St. Gallen, Switzerland. August.

Meyer, B., and J. Sullivan. 2011. "The Material Well-Being of the Poor and Middle Class Since 1980.” AEI Working Paper no. 2011-04.

Meyer, Bruce D., Wallace K. C. Mok, and James X. Sullivan. 2008. "The UnderReporting of Transfers in Household Surveys: Its Nature and Consequences." Working Paper, University of Chicago.

Mitchell, W. C., W. King, F. Macaulay, and O. Knauth. 1921. Income in the United States: Its Amount and Distribution, 1909-1919, Vol. 1. New York: National Bureau of Economic Research.

Modigliani, Franco, and Richard H. Brumberg. 1954. "Utility Analysis and the Consumption Function: An Interpretation of Cross-Section Data." In Post-Keynesian Economics, edited by Kenneth K. Kurihara, 388-436. New Brunswick: Rutgers University Press.

Mussard, S., and L. Savard. 2010. "Macro/Micro-Economic Modeling and Gini Multi-Decomposition: An Application to the Phillippines." Journal of Income Distribution 19 (2): 51-78.

Nichols, A., K. Smith, and L. Wheaton. 2011. "Analysis of Income Data Quality on the CPS ASEC." Preliminary report from Urban Institute under contract with the US Census Bureau.

Organisation for Economic Co-operation and Development (OECD). 2011. How's Life? Measuring Well-Being. Paris: OECD Publishing.

. 2012. "Reducing Income Inequality While Boosting Economic Growth: Can it be Done?" In Economic Policy Reforms 2012. Paris: OECD Publishing.

Oh, H., and R. Reis. 2011. "Targeted Transfers and the Fiscal Response to the Great Recession." NBER Working Paper no. 16775, Cambridge, MA.

Parker, J., N. Souleles, D. Johnson, and R. McClelland. 2013. "Consumer Spending and the Economic Stimulus Payments of 2008." American Economic Review 103 (6): 2530-53.

Piketty, T., and E. Saez. 2003. "Income Inequality in the United States, 1913-1998." Quarterly Journal of Economics 118 (1): 1-39.

Ramey, V. 2012. "Government Spending and Private Activity." Manuscript, University of California, San Diego. 
Reinhardt, U. E. 2011. "What Does 'Economic Growth' Mean for Americans?” New York Times, September 2.

Roemer, M. 2000. "Assessing the Quality of the March Current Population Survey and the Survey of Income and Program Participation Income Estimates, 19901996." US Census Bureau Working Paper.

Ruser, J., A. Pilot, and C. Nelson. 2004. "Alternative Measures of Household Income: BEA Personal Income, CPS Money Income, and Beyond.” US Census Bureau Working Paper.

Sabelhaus, J., D. Johnson, S. Ash, D. Swanson, T. Garner, J. Greenlees, and S. Henderson. Forthcoming. "Is the Consumer Expenditure Survey Representative by Income?" In Improving the Measurement of Consumer Expenditures, edited by C. Carroll, T. Crossley, and J. Sabelhaus..

Semega, J. 2012. "Evaluating the Construct of a Canberra Household Income Definition Using the Annual Social and Economic Supplement to the Current Population Survey (CPS ASEC).” Paper presented at Joint Statistical meetings, August. American Statistical Association.

Sen, A. 1973. On Economic Inequality. Oxford: Clarendon Press. Expanded edition, 1997.

Simons, H. 1938. Personal Income Taxation: The Definition of Income as a Problem of Fiscal Policy. Chicago: University of Chicago Press.

Slesnick, D. T. 2001. Consumption and Social Welfare: Living Standards and Their Distribution in the United States. Cambridge: Cambridge University Press.

Smeeding, T. M., and J. P. Thompson. 2011. "Recent Trends in the Distribution of Income: Labor, Wealth and More Complete Measures of Well Being." Research in Labor Economics May:1-49.

SNA (System of National Accounts). 2009. "System of National Accounts 2008." New York: European Communities, International Monetary Fund, Organisation for Economic Co-operation and Development, United Nations, and World Bank.

Stiglitz, J. E., A. Sen, and J. Fitoussi. 2009. Report by the Commission on the Measurement of Economic Performance and Social Progress. New York: United Nations Press.

Stone, J. R., and W. M. Stone. 1938. "The Marginal Propensity to Consume and the Multiplier." Review of Economic Studies 6:1-24.

Turek, J., K. Swenson, B. Ghose, F. Scheuren, and D. Lee. 2012. "How Good Are ASEC Earnings Data? A Comparison to SSA Detailed Earning Records." Paper presented at the Federal Committee on Statistical Methodology (FCSM).

Weinberg, D. 2006. "Income Data Quality Issues in the CPS." Monthly Labor Review June.

Wolff, E., A. Zacharias, T. Masterson, S. Eren, A. Sharpe, and E. Hazell. 2012. "A Comparison of Inequality and Living Standards in Canada and the United States Using an Expanded Measure of Economic Well-Being." Levy Economics Institute of Bard College Working Paper no. 703. 